\title{
Microbial and molecular identification of microbiota (Nosocomial Infection) in day care unit
}

\author{
Jummanah Sameh Showlag1, Ahmed M. Al-Hejin'1,2, Noor Mohammed Bataweel1,2, Mohamed Abu-Zaid ${ }^{1,3}$, \\ Maged Mostafa Mahmoud ${ }^{2,4}$, Azhar Abdullah Najjar ${ }^{1,2}$, Mohamed Morsi M. Ahmed ${ }^{1,5}$
}

1Department of Biological Sciences, Faculty of Science, P.O. Box 80203, King Abdulaziz University, Jeddah, 21589, Saudi Arabia. ${ }^{2}$ King Fahad Medical Research Center, P.O. Box 80216, King Abdulaziz University, Jeddah, 21589, Saudi Arabia.

${ }^{3}$ Microbial Genetics Department, Genetic Engineering and Biotechnology Division, National Research Center, Dokki, Giza, Egypt.

${ }^{4}$ Molecular Genetics and Enzymology Department, Human Genetics and Genome Research, National Research Center, Cairo, Egypt.

${ }^{5}$ Nucleic Acids Research Dept., Genetic Engineering, and Biotechnology Research Institute (GEBRI). City for Scientific Research and Technological

Applications. Alexandria, Egypt.

Correspondence Author: Jummanah Sameh Showlag, Department of Biological Sciences, Faculty of Science, P.0. Box 80203, King Abdulaziz University, Jeddah, 21589, Saudi Arabia.

Received date: 12 November 2018, Accepted date: 10 January 2019, Online date: 25 January 2019

Copyright: (C) 2019 Jummanah Sameh Showlag et al., This is an open-access article distributed under the terms of the Creative Commons Attribution License, which permits unrestricted use, distribution, and reproduction in any medium, provided the original author and source are credited.

\begin{abstract}
Patients in the hospital are usually immunocompromised. So, Nosocomial infection or healthcare-associated infections (HAIs), which described as onset more than 48 hours after hospital admission, are a severe issue for the patients in Day care units (DCUs). It is responsible for the increase of mortality, morbidity and the duration of stay in the hospital. About one out of 25 patients have a minimum one nosocomial infection. The environment that surrounds the patients is crowded by equipment for monitoring and organ support (e.g., monitors, ventilator, extracorporeal life support machines). Moreover, the bacteria infectious may come from many different sources (e.g., individuals in the hospital, healthcare hand's, on surfaces, or equipment). HAIs regularly rise as a result of the formation of biofilms at the surfaces of these medical devices. The most gram-positive bacteria that because HAIs are Group B Streptococci, Listeria, Staphylococcus aureus, Methicillin-resistant S. aureus ...etc. As for gram-negative bacteria such as Escherichia coli, Enterobacter, Klebsiella, Pseudomonas, Serratia, Salmonella... etc. some of these bacteria are resistance for most of the antibiotics. This review aims to support our information about the Epidemiology of nosocomial infections.
\end{abstract}

Key words: Microbial, Molecular, PCR, Microbiota, 16s rRNA, infection, day care

\section{INTRODUCTION}

Any disease acquired by the patient under medical care call Nosocomial infection or " "associated healthcare infections.[1] Health facility-obtained infections seemed earlier than the origination of hospitals and have become a health trouble throughout the miraculous antibiotic era. due to these infections, no longer simplest the costs however additionally using antibiotics increased with an prolonged hospitalization. This led to extended morbidity and mortality.[1],[2]

The most common nosocomial infections are infections of surgical wounds, urinary tract infections, and lower respiratory tract infections. The WHO observe, and others, have also shown that the highest occurrence of nosocomial infections happens in extensive care devices and in acute surgical and orthopedic wards. contamination costs are higher amongst patients with elevated susceptibility due to antique age, underlying disease, or chemotherapy.

Nosocomial infection impacts big wide variety of patients globally, elevating mortality charge and monetary losses significantly. in step with estimate reported of WHO, about $15 \%$ of all hospitalized patients suffer from these infections. these infections are chargeable for $4 \%-56 \%$ of all dying reasons in neonates, with incidence rate of $75 \%$ in South-East Asia and SubSaharan Africa. The prevalence is high enough in high income countries i.e. between 3.5\% and $12 \%$ while it varies between $5.7 \%$ and $19.1 \%$ in middle- and low-income countries. The frequency of general infections in low earnings countries is three times higher than in high income countries while this occurrence is 3-20 times higher in neonates. 
Other studies conducted in different parts of the world display that during North America and Europe 5\%-10\% of all hospitalizations result in nosocomial infections, while Latin the USA, Sub-Saharan Africa, and Asia display greater than 40\% hospitalizations with nosocomial infection.[3]

\section{Epidemiology of nosocomial infections:}

The accelerated morbidity and mortality related to nosocomial infections is an issue of serious concern nowadays. extreme medicolegal troubles additionally arise in this context, because the affected person or their households occasionally blame the sanatorium body of workers for the contamination and call for compensation. it's been mentioned that in hospitals with an effective application for nosocomial contamination surveillance, infection rates can be reduced by means of about one-third. The development of a nosocomial infection is a sequence of activities, that's prompted with the aid of the microbe, transmission route, and the patient himself. [3]

\section{kinds of nosocomial infections}

National Healthcare safety network with center for disease control (CDC) for surveillance has labeled nosocomial infection sites into 13 kinds, with 50 infection sites, which might be unique on the basis of biological and medical criteria The sites which are common include

- Urinary infections: This is the most common nosocomial infection and it less morbidity than other nosocomial infections caused by Streptococcus pneumoniae. [4]

- Surgical site infections (SSI) : Nosocomial infections be fall in $2 \%-5 \%$ of patients subjected to surgery. These are the second most common kind of nosocomial infection caused explicitly by Staphylococcus aureus resulting in extended hospitalization and risk of death.

The pathogens inflicting SSI arise from endogenous microflora of the patient. The incidence can be as high as $20 \%$ relying upon method and surveillance standards used.

Other bacteria cause this infection:

Streptococcus spp, Enterococcus spp. [3],[5]

- Nosocomial pneumonia: patients on ventilators in intensive care units, where the rate of pneumonia is $3 \%$ per day.

- Other nosocomial infections: Nosocomial bloodstream, Nosocomial diarrhea, and Nosocomial meningitis. [3]

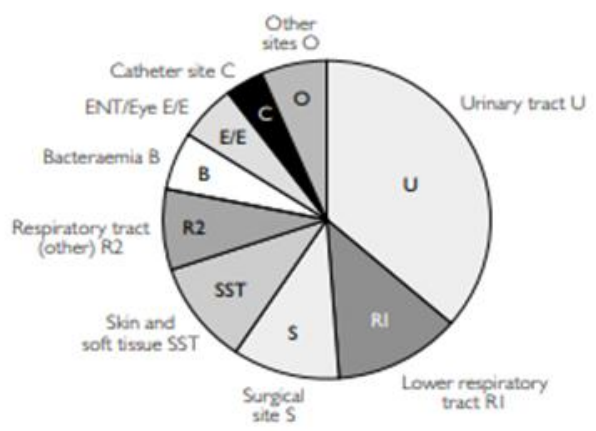

Figure1: Sites of the most common nosocomial infections: distribution according to the French national prevalence survey. [3]

\section{Factors influencing the development of nosocomial infections}

- The microbial agent

Many different bacteria, viruses, fungi, and parasites may purpose nosocomial infections. Infections can be resulting from a microorganism obtained from another person in the hospital (cross-infection). Alternatively, maybe resulting from the patient's flora (endogenous infection). Some organisms may be received from an inanimate object or contaminated from any other human source (environmental infection). [1],[6]

- Patient susceptibility:

Critical patient elements influencing the acquisition of infection include age, immune status, underlying disease, and diagnostic and therapeutic interventions. The extremes of life — infancy and old age — are related to a decreased resistance to infection. Patients with chronic disease consisting of malignant tumors, leukemia, diabetes mellitus, renal failure, or the received immunodeficiency syndrome (AIDS) have an increased susceptibility to infections with opportunistic pathogens. [3]

- Environment:

Health care settings are an environment where each infected persons and people at increased risk of infection congregate. Microbial flora can also contaminate objects, devices, and substances which subsequently contact inclined body sites of patients. Further, new infections related to bacteria which include waterborne bacteria (atypical mycobacteria) and viruses and parasites remain identified.[3]

- Bacterial resistance: 
Many patients receive antimicrobial drugs. Via choice and change of genetic resistance elements, antibiotics sell the emergence of multidrug-resistant strains of bacteria; microorganisms in the normal human flora sensitive to the given drug are suppressed, even as resistant strains persist and can become endemic inside the hospital.

An antimicrobial agent becomes broadly used, bacteria resistant to this drug eventually emerge and may unfold within the health care setting. Many strains of pneumococci, staphylococci, enterococci, and tuberculosis are presently resistant to most or all antimicrobials which had been once useful. Multi-resistant Klebsiella and Pseudomonas aeruginosa are common in many hospitals. This problem is significant in growing countries in which higher priced second-line antibiotics might not be available or less costly.[1],[7].

\section{Reservoirs and transmission}

- Microflora of the patient:

The microorganism belonging to the endogenous flora of the patient can purpose infections if they may be transferred to a tissue wound or surgical site. Gram-negative bacteria in the digestive tract purpose SSI after abdominal surgery. [3]

- $\quad$ Patient and staff:

Bacteria are transmitted between patients: (a) via direct contact among patients (hands, saliva droplets or different body fluids), (b) inside the air (droplets or dirt contaminated via a patient's bacteria), $\quad$ (c) through group of workers contaminated through patient care (hands, clothes, nose and throat) who become transient or permanent carriers, subsequently transmitting bacteria to different patients through direct touch at some point of care, (d) via objects contaminated by the patient (including equipment), the team of worker's hands, traffic or other environmental sources (e.g. water, other fluids, food). [3]

- Health care environment

Pathogens living in the healthcare surroundings, i.e. water, food, and equipment may be a supply of transmission to the different patient makes one extra reservoir for the uninfected patient.

Table 1: Types and percentages of the bacterial isolates in different environmental samples in the studied ICUs [8].

\begin{tabular}{|c|c|c|c|c|c|c|c|c|c|c|c|c|c|}
\hline $\begin{array}{l}\text { Site of } \\
\text { isolation, } \\
N \text { (S) }\end{array}$ & $\begin{array}{l}\text { S. } \\
\text { aureus }\end{array}$ & $\begin{array}{l}K . \\
\text { pneumoniae }\end{array}$ & $\begin{array}{l}\text { S. } \\
\text { saprophyticus }\end{array}$ & S. & A. & $\begin{array}{l}\boldsymbol{P} \\
\text { aeruginosa }\end{array}$ & $\begin{array}{l}\text { E. } \\
\text { coll }\end{array}$ & Enterobacter & Streptococdi & $\begin{array}{l}\text { Bacillus } \\
\text { spo. }\end{array}$ & $\begin{array}{l}\text { Proteus } \\
\$ \$ 90\end{array}$ & $\begin{array}{l}\text { Enterococcus } \\
\text { spp. }\end{array}$ & Total \\
\hline $\begin{array}{l}\text { Ambu bas } \\
\text { (14) }\end{array}$ & 0 & $1(7.14)$ & 0 & $1(7.14)$ & 0 & 0 & 0 & 0 & 0 & $1(7.19)$ & 0 & 0 & $\begin{array}{l}3 \\
(21.43)\end{array}$ \\
\hline $\begin{array}{l}\text { Nurse's } \\
\text { stasion } \\
\text { (16) }\end{array}$ & 0 & 0 & 0 & $1(6.25)$ & $3(18.75)$ & 0 & 0 & 0 & 0 & 0 & 0 & 0 & $4(2)$ \\
\hline $\begin{array}{l}\text { Orypen } \\
\text { mask (11) }\end{array}$ & $1(9.09)$ & 0 & 0 & $1(909)$ & $5(45.45)$ & 0 & (9.09) & 0 & 0 & 0 & 0 & $1(909)$ & $\stackrel{9}{(8181)}$ \\
\hline $\begin{array}{l}\text { Ventialser } \\
\text { (117) }\end{array}$ & $\begin{array}{l}16 \\
(1368)\end{array}$ & $6(5.13)$ & 0 & $26(22.22)$ & 39 (33.33) & $1(0.85)$ & $\begin{array}{l}1 \\
(0.85)\end{array}$ & 0 & 0 & $4(3.42)$ & $2(1.71)$ & $2(1.71)$ & $\begin{array}{l}97 \\
\text { (to2 91) }\end{array}$ \\
\hline Bed (128) & $\begin{array}{l}14 \\
(10.94)\end{array}$ & $1(0.78)$ & 0 & $25(19.53)$ & $16(12.5)$ & $3(234)$ & (0.75) & 0 & $3(234)$ & $1(0.75)$ & 0 & $1(0.78)$ & $\begin{array}{l}65 \\
(50.70)\end{array}$ \\
\hline $\begin{array}{l}\text { Patents } \\
\text { tabin (124) }\end{array}$ & $7(5.65)$ & $2(1.62)$ & 0 & $25(22.55)$ & $13(10.48)$ & $2(1.61)$ & 0 & $2(161)$ & 0 & $2(1.61)$ & 0 & 0 & $\begin{array}{l}58 \\
(55,65)\end{array}$ \\
\hline $\begin{array}{l}\text { Bed Inen } \\
(34)\end{array}$ & $\begin{array}{l}5 \\
(14.71)\end{array}$ & 0 & 0 & $4(11.76)$ & $12(35.3)$ & 0 & 0 & 0 & 0 & & 0 & $2(588)$ & (67 65) \\
\hline $\begin{array}{l}\text { Pattent } \\
\text { Siles (97) }\end{array}$ & $4(4.12)$ & 0 & $1(1.09)$ & $15(15.45)$ & $8(8.24)$ & 0 & 0 & 0 & $1(1.09)$ & $2(207)$ & 0 & 0 & $3196)$ \\
\hline $\begin{array}{l}\text { Phone } \\
\text { handset } \\
\text { (t) }\end{array}$ & $1(12.5)$ & 0 & 0 & $1(125)$ & 0 & 0 & 0 & 0 & 0 & & 0 & 0 & $2(25)$ \\
\hline $\begin{array}{l}\text { Others } \\
\text { (56) }\end{array}$ & $1(1.79)$ & $1(1.79)$ & $1(1.79)$ & $11(1964)$ & $4(7.14)$ & $2(357)$ & 0 & 0 & 0 & $1(1.79)$ & 0 & $2(357)$ & $l_{(41.07)}^{23}$ \\
\hline
\end{tabular}

\section{A microorganism that causes Nosocomial Infection}

- Commensal microorganism: Located in the normal flora of healthy human beings. A few commensal microorganism can also purpose infection if the natural host is compromised. For example Staphylococci cause intravascular line infection, and intestinal Escherichia coli cause a urinary infection.

- Pathogenic bacteria:

- Anaerobic Gram-positive rods (e.g., Clostridium) cause gangrene.

- Gram-positive bacteria: Staphylococcus aureus cause a huge kind of lung, bone, heart and bloodstream infections and it is resistant to antibiotics.

- Gram-negative bacteria: Enterobacteriacae (e.g. Escherichia coli, Proteus, Klebsiella, Enterobacter, Serratia marcescens) cause serious infections (surgical site, lung, bacteraemia, peritoneum infection).

- Gram-negative organisms such as Pseudomonas spp. They may colonize the digestive tract of hospitalized patients.

- Selected different bacteria are an utterly unique risk in hospitals. For example Legionella species may cause pneumonia through inhalation of aerosols containing infected water (air conditioning, showers, healing aerosols).

- Antibiotic resistance: 
Antibiotic resistance is chargeable for the dying of child every five minutes in South-East Asia area. Drugs that had been used to treat deadly diseases at the moment are dropping their impact due to rising drug-resistant microorganisms. Self-medication with antibiotics, incorrect dosage, prolonged use, loss of standards for healthcare workers and misuse in animal husbandry are the principle elements answerable for an increase in resistance. This resistance threatens the effective control towards microorg anism that reasons UTI, pneumonia and bloodstream infections.

An exceedingly resistant microorganism consisting of MRSA or multidrug-resistant Gram-bad microorganism is the cause of excessive occurrence charges of nosocomial infections international. South-East Asian region reports display that there an excessive resistance in E. coli and ok. pneumonia for third technology cephalosporin and greater than the zone of $S$. aureus infections are methicillin resistant. Immediately action is needed to stop the sector from heading towards pre-antibiotic technology wherein all achievements made in prevention and control of communicable illnesses can be reversed stated Dr. Poonam Khetrapal Singh, nearby Director of WHO South-East Asia vicinity.

- Viruses, Parasites, and fungi: Viruses is the possibility of nosocomial transmission of many viruses, including the hepatitis B and $\mathrm{C}$ viruses. A few parasites (e.g. Giardia lamblia) are transmitted easily amongst adults or youngsters. Many fungi and other parasites are opportunistic organisms and cause infection throughout prolonged antibiotic treatment moreover, extreme immunosuppression (Candida albicans, Aspergillus spp., Cryptococcus neoformans, Cryptosporidium). [3]

Table 2: Frequency of bacterial species detected in the ICU environments and hands of the ICUs' staff among six hospitals. [8]

\begin{tabular}{|c|c|c|c|c|c|c|c|c|c|c|c|c|}
\hline $\begin{array}{l}\text { Bacterial } \\
\text { isolates, } N \\
(\%)\end{array}$ & $\begin{array}{l}\text { S. } \\
\text { aureus }\end{array}$ & $\begin{array}{l}K . \\
\text { pneumoniae }\end{array}$ & $\begin{array}{l}\text { S. } \\
\text { saprophyticus }\end{array}$ & $\begin{array}{l}\text { S. } \\
\text { epidermidis }\end{array}$ & $\begin{array}{l}\text { A. } \\
\text { baumannii }\end{array}$ & $\begin{array}{l}P . \\
\text { aeruginosa }\end{array}$ & $\begin{array}{l}\text { E. } \\
\text { coli }\end{array}$ & Enterobacter & Streptococci & $\begin{array}{l}\text { Bacillus } \\
\text { spp. }\end{array}$ & $\begin{array}{l}\text { Proteus } \\
\text { spp. }\end{array}$ & $\begin{array}{l}\text { Enterococcus } \\
\text { spp. }\end{array}$ \\
\hline $\begin{array}{l}\text { ICU } \\
\text { environment }\end{array}$ & $49(8.1)$ & $11(1.8)$ & $2(0.3)$ & $113(18.7)$ & $100(16.5)$ & $8(1.3)$ & $\begin{array}{l}3 \\
(0.5)\end{array}$ & $2(0.3)$ & $4(0.7)$ & $11(1.8)$ & $2(0.3)$ & $8(1.3)$ \\
\hline $\begin{array}{l}\text { HCWS } \\
\text { hands }\end{array}$ & $47(5.9)$ & $O(0)$ & $1(0.1)$ & $166(20.9)$ & $11(1.4)$ & $O(0)$ & $0(0)$ & $O(0)$ & $16(2.01)$ & $14(1.8)$ & $0(0)$ & $8(1)$ \\
\hline
\end{tabular}

Table 2: Frequency of bacterial species detected in the ICU environments and hands of the ICUs' staff among six hospitals. [8]

\section{Hospital Hygiene:}

A main risk in the hospital is the advent of pathogens which could cause infection. Failure to correctly disinfect or sterilize equipment incorporates not only danger associated with a breach of host barriers but also a risk for person-to-person transmission (e.g., hepatitis B virus) and transmission of environmental pathogens (e.g., Pseudomonas aeruginosa).

Disinfection and sterilization are vital for ensuring that medical and surgical devices do not transmit infectious pathogens to patients. Because sterilization of all patient-care objects is not essential, health-care guidelines must become aware of, primarily on the premise of the objects' meant use, whether cleaning, disinfection, or sterilization is indicated.

Multiple studies in many countries have documented the loss of compliance with set up suggestions for disinfection and sterilization. Failure to comply with scientifically-based guidelines has caused several outbreaks [9].

- Cleaning:

Cleaning is the elimination of foreign material (e.g., soil, and natural material) from objects and is usually completed with use of water with detergents or enzymatic products. Thorough cleaning is needed before high-level disinfection and sterilization because inorganic and organic materials that stay on the surfaces of instruments intrude with the effectiveness of those processes. Also, if soiled substances dry or bake onto the units, the elimination procedure will become harder and the disinfection or sterilization technique much less powerful or ineffective. Surgical devices must be presoaked or rinsed to prevent drying of blood and to soften or dispose of blood from the devices.

Mechanical or automated cleaners are ultrasonic cleaners, washing machine-decontaminators, washer-disinfectors, and washing machine-sterilizers is the most common kinds of cleaning.

Ultrasonic cleaning solutions (and different used detergent solutions) can make Bacterial contamination because those solutions usually do not make antibacterial label claims. Also endotoxin contamination of surgical devices resulting from ultrasonic cleaners that may cause severe inflammatory reactions users.

Cleaning makes the effectiveness of disinfection and sterilization in high-level. In a clinical setting, there is no verify to cleaning test. To ensure an adequate level of cleaning they can be used commercially available reprocessing verification test (e.g., microbiologic sampling). [9]

\section{- Disinfectant:}

Disinfection describes a procedure that removes many or all pathogenic microorganisms, except bacterial spores, on inanimate items. In health-care settings, items commonly are disinfected through liquid chemical compounds or moist pasteurization. Every of the different factors that affect the efficacy of disinfection can nullify or limit the efficacy of the method. [9] 
- Disinfectant level:

- High-level disinfection (critical) - this could destroy all microorganisms, except for heavy contamination via bacterial spores.

- Intermediate disinfection (semi-critical) this inactivates Mycobacterium tuberculosis, vegetative bacteria, most viruses, and most fungi, but does not necessarily kill bacterial spores

- Low-level disinfection (non-critical) - this can kill most bacteria, some viruses and some fungi, but cannot be relied on for killing more resistant bacteria such as M. tuberculosis or bacterial spores. [3]

Table 3: Spectrum of activity achieved of the main disinfectants, [3].

\begin{tabular}{|c|c|c|c|}
\hline $\begin{array}{l}\text { Level of } \\
\text { disinfection } \\
\text { required }\end{array}$ & $\begin{array}{l}\text { Spectrum of } \\
\text { activity of } \\
\text { desinfectant }\end{array}$ & $\begin{array}{l}\text { Active ingredients potentially } \\
\text { capable of satisfying these } \\
\text { spectra of activity }\end{array}$ & $\begin{array}{l}\text { Factors affecting } \\
\text { the efficacy of } \\
\text { a disinfectant }\end{array}$ \\
\hline High & $\begin{array}{l}\text { - Sporicidal } \\
\text { - Mycobactericidal } \\
\text { - Virucidal } \\
\text { - Fungicidal } \\
\text { - Bactericidal }\end{array}$ & $\begin{array}{l}\text { - Peracetic acid } \\
\text { - Chlorine dioxide } \\
\text { - Formaldehyde } \\
\text { - Glutaraldehyde } \\
\text { - Sodium hypochlorite } \\
\text { - Stabilized hydrogen peroxide } \\
\text { - Succinaldehyde (succinic aldehyde) }\end{array}$ & \multirow{3}{*}{$\begin{array}{l}\text { - Concentration } \\
\text { - Contact time } \\
\text { - Temperature } \\
\text { - Presence of organic matter } \\
\text { - pH } \\
\text { - Presence of calcium or magnesium } \\
\text { ions (for example, hardness of the } \\
\text { water used for dilution) } \\
\text { - Formulation of the disinfectant } \\
\text { used }\end{array}$} \\
\hline Intermediate & $\begin{array}{l}\text { - Tuberculocidal } \\
\text { - Virucidal } \\
\text { - Fungicidal } \\
\text { - Bactericidal }\end{array}$ & $\begin{array}{l}\text { - Phenol derivatives } \\
\text { - Ethyl and isopropyl alcohols }\end{array}$ & \\
\hline Low & - Bactericidal & $\begin{array}{l}\text { - Quaternary ammonium } \\
\text { - Amphiprotic } \\
\text { - Amino acids }\end{array}$ & \\
\hline
\end{tabular}

- Methods of Disinfection: [9]

Chemical Disinfectants:

$\checkmark$ Alcohol

$\checkmark$ Chlorine and chlorine compounds

$\checkmark$ Formaldehyde

$\checkmark$ Glutaraldehyde

$\checkmark$ Hydrogen peroxide

$\checkmark$ Iodophors

$\checkmark$ Ortho-phthalaldehyde (OPA)

$\checkmark$ Peracetic acid

$\checkmark \quad$ Peracetic acid and hydrogen peroxide

$\checkmark$ Phenolics

$\checkmark$ Quaternary ammonium compounds

Miscellaneous Inactivating Agents:
$\checkmark$ Germicides
$\checkmark$ Metals as microbicides
$\checkmark$ Ultraviolet radiation
$\checkmark$ Pasteurization
$\checkmark$ Flushing- and washer-disinfectors 


\begin{tabular}{|lll|}
\hline Resistant & & \multicolumn{1}{c|}{ Level } \\
& Prions (Creutzeldt-Jakob Disease) & Prion reprocessing \\
& Bacterial spores (Bacillus atrophaeus) & Sterilization \\
& Coccidia (Cryptosporidium) & Disinfection \\
& Mycobacteria (M. tuberculosis, M. terrae) & High \\
& Nonlipid or small viruses (polio, coxsackie) \\
& Fungi (Aspergillus, Candida) \\
& Vegetative bacteria (S. aureus, P. aeruginosa) \\
Susceptible & Lipid or medium-sized viruses (HIV, herpes, hepatitis B)
\end{tabular}

Figure 2: Decreasing order of resistance of microorganisms to disinfection and sterilization and the level of disinfection or sterilization

- Sterilization:

Sterilization describes a procedure that destroys or removes all kinds of microbial life and is carried out in health-care facilities via physical or chemical techniques. Steam under pressure, dry heat, EtO gas, hydrogen peroxide gas plasma, and liquid chemical are the principal sterilizing agents used in healthcare facilities. [9]

Sterilization method:

- Thermal sterilization:

$\checkmark \quad$ Wet sterilization: exposure to steam saturated with water at $121{ }^{\circ} \mathrm{C}$ for 30 minutes, or $134{ }^{\circ} \mathrm{C}$ for 13 minutes in an autoclave; $\left(134^{\circ} \mathrm{C}\right.$ for 18 minutes for prions).

$\checkmark$ Dry sterilization: exposure to $160{ }^{\circ} \mathrm{C}$ for 120 minutes, or $170{ }^{\circ} \mathrm{C}$ for 60 minutes; this sterilization process is often considered less reliable than the wet process, particularly for hollow medical devices.

- Chemical sterilization:

$\checkmark$ Ethylene oxide and formaldehyde for sterilization are being phased out in many countries because of safety and greenhouse gas emission concerns.

Peracetic acid is widely used in the United States and some other countries in automatic processing systems [3].

\section{CONCLUSIONS}

Increase the rate of nosocomial infection in current years that increase the rate of death. The responsible for this infection pathogenic microorganism. hospital infection control should devise a way to control hygiene.

\section{CONFLICT OF INTEREST}

The authors declare no conflicts of interest.

\section{ACKNOWLEDGMENT}

This work support from King Abdulaziz City for Sciences and Technologies (KACST) in the Saudi Arabia, and thanks to the King Abdulaziz University hospital, Jeddah, Saudi Arabia. The authors also, acknowledge assistance from the Science \& Technology Unit, Deanship of Scientific Research and Deanship of Graduate Studies, and, acknowledge support from the Dept. of Biological Sciences, Faculty of Science, King Abdulaziz University (KAU), Jeddah, KSA.

\section{REFERENCE}

1. Ahmed Khan H, Ahmad A, Mehboob R, 2015. Nosocomial infections and their control strategies. Asian Pacific Journal of Tropical Biomedicine. 5(7):509-514

2. Brusaferro S, Arnoldo L, Cattani G, Fabbro E, Cookson B, Gallagher R, 2015. Harmonizing and supporting infection control training in Europe. J Hosp Infect, 89(4):351-356.

3. WHO 2015. Prevention of hospital-acquired infections..

4. Burckhardt I, Zimmermann S, 2011. Streptococcus pneumoniae in Urinary Tracts of Children with Chronic Kidney Disease. Emerging Infectious Diseases, 17(1):120-122. 
5. Shinagawa N, Hoshikawa T, Oshima H, Aikawa N, Sasaki J, Suzuki M, Serine K, Abe S, Takeyama H, Wakasugi T, Mashita K, Tanaka M, Mizuno A, Ishikawa M, Iwai A, Saito T, Muramoto M, Kubo S, Lee S, Fukuh, 2014. Bacteria isolated from surgical infections and its susceptibilities to antimicrobial agents - Special references to bacteria isolated between April 2010 and March 2011. Japanese Journal of Antibiotics, 67(5):293-334.

6. Horan TC, Andrus M, Dudeck AM, 2008. CDC/NHSN surveillance definition of health care-associated infection and criteria for specific types of infections in the acute care setting. Am J Infect Control, 36 (5): 309-332.

7. Klein E, Smith DL, Laxminarayan R, 2007. Hospitalizations and deaths caused by methicillin-resistant Staphylococcus aureus, United States, 1999-2005. Emerg Infect Dis, 13(12):1840-1846.

8. Abozed M, Abd El, Latif H, Serry F, El Sayed L, 2013. Correlating Neonates' Bacterial Isolates with Surrounding Environment in NICU and Detection of Biofilm Formation. Research Journal of Pharmacy and Technology, 6(7): 794-801.

9. CDC, 2016. Guideline for Disinfection and Sterilization in Healthcare Facilities.

10. Ahmed Khan H, Kanwal Baig F, Mehboob R, 2017. Nosocomial infections: Epidemiology, prevention, control and surveillance. Asian Pacific Journal of Tropical Biomedicine7(5):478-482.

11. L Raka, L MD, MS D, Zoutman, MD, FRCPC, G. Mulliqi, MD, PhD, S. Krasniqi , MD, PhD, I. Dedushaj, MD, PhD, N. Raka , MD, S. Ahmeti , MD, PhD, M. Shala , MD, PhD, A. Vishaj, MD and Y. Elezi , MD, PhD., 2006. Prevalence of Nosocomial Infections in High-Risk Units in the University Clinical Center of Kosova. infection control and hospital epidemiology 27(4):421-423. 